\title{
Real-time assessment of daytime sleepiness in drivers with multiple sclerosis
}

\section{Names and institutional affiliations of the authors}

Hannes Devos, PT, PhD, ${ }^{1}$ Nesreen Alissa, $\mathrm{MS}^{2}$ Sharon Lynch, $\mathrm{MD}^{3}$ Maryam

Sadeghi, $\mathrm{MS}^{4}$ Abiodun E. Akinwuntan, PhD, MPH, MBA ${ }^{5}$ Catherine Siengsukon, PT, $\mathrm{PhD}^{1}$

${ }^{1}$ Department of Physical Therapy and Rehabilitation Science, School of Health

Professions, University of Kansas Medical Center, Kansas City KS

${ }^{2}$ Department of Physical Therapy and Rehabilitation Science, School of Medicine, University of Maryland Baltimore, Baltimore MD

${ }^{3}$ Department of Neurology, School of Medicine, University of Kansas Medical Center, Kansas City KS

${ }^{1,4}$ Department of Exercise Physiology, Faculty of Physical Education \& Sport Sciences, University of Tehran, Tehran, Iran

${ }^{5}$ Office of the Dean, School of Health Professions, University of Kansas Medical Center, Kansas City KS

\section{Name and address for corresponding author}

Hannes Devos

Department of Physical Therapy and Rehabilitation Science, University of Kansas

Medical Center, 3901 Rainbow Blvd., Kansas City KS

Tel: $913-588-2840$

Fax: 913-588-5254

E-mail: hdevos@kumc.edu 
medRxiv preprint doi: https://doi.org/10.1101/2020.06.19.20136077; this version posted June 20, 2020. The copyright holder for this preprint (which was not certified by peer review) is the author/funder, who has granted medRxiv a license to display the preprint in perpetuity.

\begin{abstract}
Background: Daytime sleepiness is a common symptom of multiple sclerosis (MS) that may jeopardize safe driving. The aim of this study was to compare daytime sleepiness, recorded in real-time through eyelid tracking, in a simulated drive between individuals with MS (iwMS) and healthy controls.

Methods: Fifteen iwMS (age = median (Q1 - Q3), $55(50-55)$; EDSS = $2.5(2-3.5)$; $12(80 \%)$ female) were matched for age, sex, education, and cognitive status with 15 controls. All participants completed self-reported fatigue and sleepiness scales including the Modified Fatigue Impact Scale (MFIS), Pittsburg Sleep Quality Inventory (PSQI), and Epworth Sleepiness Scale (ESS). Percentage of eyelid closure (PERCLOS) was extracted from a remote eye tracker while completing a simulated drive of 25 minutes.
\end{abstract}

Results: Although iwMS reported more symptoms of fatigue (MFIS, $p=0.003$ ) and poorer sleep quality (PSQI, $p=0.008$ ), they did not report more daytime sleepiness (ESS, $p=0.45)$. Likewise, there were no differences between groups in real-time daytime sleepiness, indexed by PERCLOS $(p=0.82)$. Both groups exhibited more realtime daytime sleepiness as they progressed through the drive (time effect, $p<0.0001$ ). The interaction effect of group ${ }^{*}$ time $(p=0.05)$ demonstrated exacerbated symptoms of daytime sleepiness towards the end of the drive in iwMS compared to controls.

PERCLOS correlated strongly (Spearman $\rho=0.76, p=0.001$ ) with distance out of lane in iwMS.

Conclusion: IwMS show exacerbated symptoms of daytime sleepiness during monotonous, simulate drive. Future studies are warranted to investigate the effect of MS on daytime sleepiness during real-world driving. 
medRxiv preprint doi: https://doi.org/10.1101/2020.06.19.20136077; this version posted June 20, 2020. The copyright holder for this preprint (which was not certified by peer review) is the author/funder, who has granted medRxiv a license to display the preprint in perpetuity.

All rights reserved. No reuse allowed without permission.

Keywords: multiple sclerosis; daytime sleepiness; PERCLOS; virtual reality; driving simulator 
medRxiv preprint doi: https://doi.org/10.1101/2020.06.19.20136077; this version posted June 20, 2020. The copyright holder for this preprint (which was not certified by peer review) is the author/funder, who has granted medRxiv a license to display the preprint in perpetuity.

1. Introduction

Although fatigue and daytime sleepiness are sometimes used interchangeably, they encompass distinct constructs that are often affected in multiple sclerosis (MS). ${ }^{1}$ Both can be a consequence of sleep disorders. ${ }^{2,3}$ Fatigue is a "subjective lack of physical and/or mental energy that is perceived by the individual or the caregiver to interfere with usual and desired activities." ${ }^{4}$ Fatigue is reported in up to $90 \%$ of individuals with MS (iwMS), ${ }^{5}$ and $40 \%$ of iwMS reports fatigue is their worst symptom. ${ }^{6}$ Although daytime sleepiness is less prevalent and severe than fatigue, a substantial percentage (19\% to $53 \%$ ) of iwMS report feeling sleepy or drowsy during the day. ${ }^{3}$ Daytime sleepiness is defined as the "inability to stay awake and alert during the major waking episodes of the day, resulting in periods of irrepressible need for sleep or unintended lapses into drowsiness or sleep. ${ }^{7}$ Daytime sleepiness is due to an imbalance in the sleep promoting and wake promoting neuronal systems. ${ }^{1}$

The occurrence of daytime sleepiness in MS gives rise to several concerns regarding its impact on specific aspects of daily life including driving. The lack of cognitive stimulation from monotonous driving may exacerbate daytime sleepiness. Lapses of drowsiness or sleep are associated with loss of vehicle control, and out-of-lane excursions. ${ }^{8}$ This puts drivers at an increased risk of motor vehicle crashes (MVC). ${ }^{9}$ Around $77 \%$ of iwMS continue driving after being diagnosed. ${ }^{10}$ Individuals with MS tend to alter their driving habits by driving less frequently and adopting more self-limiting behaviors. ${ }^{11}$ Although the vast majority of drivers with MS are fit to drive following an on-road test, ${ }^{12}$ they are reported to have greater frequency of driving violations, ${ }^{13}$ vehicle collisions, ${ }^{14}$ and hospital visits following a car crash ${ }^{15}$ compared to healthy controls. Impairments in 
medRxiv preprint doi: https://doi.org/10.1101/2020.06.19.20136077; this version posted June 20, 2020. The copyright holder for this preprint (which was not certified by peer review) is the author/funder, who has granted medRxiv a license to display the preprint in perpetuity.

All rights reserved. No reuse allowed without permission.

cognitive functions, particularly in speed of processing, attention, and visuospatial and executive functions, have emerged as most important predictors of on-road driving performance. ${ }^{16}$ The effect of daytime sleepiness on driving performance in iwMS has yet to be established.

The Epworth Sleepiness Scale (ESS) is perhaps the most ubiquitous daytime sleepiness assessment of iwMS. ${ }^{17}$ Although the ESS provides a fast, reliable, and accurate assessment of daytime sleepiness, the questionnaire relies on subjective selfrecall of the participant, ${ }^{17}$ and lacks the ability to monitor sleepiness continuously in reallife activities. ${ }^{18,19}$ Sleepiness is a gradual process that includes a sequence of physiological and behavioral changes. ${ }^{20}$ Observable changes in eye movement, eyelid behavior, head nodding, and facial expression have been associated with increased daytime sleepiness. ${ }^{21}$ The PERcentage of eye lid CLOSure (PERCLOS) on the pupil over time may be the most widely accepted eye tracking method for vigilance and sleepiness detection in human-machine interface studies, such as driving, ${ }^{22}$ and aviation. ${ }^{23}$ Unlike ESS, PERCLOS can be used to monitor daytime sleepiness in realtime during functional activities such as driving in iwMS.

The aim of this study was to compare the effect of a monotonous driving task on daytime sleepiness, indexed by PERCLOS, between iwMS and healthy controls.

\section{Materials and Methods}

\subsection{Participants}


medRxiv preprint doi: https://doi.org/10.1101/2020.06.19.20136077; this version posted June 20, 2020. The copyright holder for this preprint (which was not certified by peer review) is the author/funder, who has granted medRxiv a license to display the preprint in perpetuity.

All rights reserved. No reuse allowed without permission.

Participants with a clinical diagnosis of MS according to the McDonald Criteria were recruited from the University of Kansas Multiple Sclerosis Clinic. Inclusion criteria were (1) between the ages of 18 and 65; (2) ability to understand the instructions in English; (3) in possession of a valid driver's license; and (4) actively driving at the moment of testing with or without adaptive devices. Exclusion criteria were: (1) ocular motility problems such as nystagmus or cranial nerve palsy (III, IV, VI), (2) unresolved retina or pupillary conditions; (3) currently taking steroids, benzodiazepines, or neuroleptics; (4) exacerbations in the month preceding testing; (5) history of any substance abuse; and (6) history of a neurological disorder other than MS. From 06/01/2018 - 05/31/2019, 15 participants with MS were recruited and matched with 15 healthy controls according to age, sex, education, and cognitive status.

\subsection{Procedure}

All testing took place in less than 1.5 hours including consent and rest breaks. The study was approved by the University of Kansas Institutional Review Board. All participants provided informed consent.

\subsubsection{Demographic and clinical information}

Age, sex, and education level were recorded. Cognition was evaluated using the Montreal Cognitive Assessment (MOCA) ${ }^{24}$ Clinical information included years since diagnosis, Expanded Disability Status Scale (EDSS) score, ${ }^{25}$ and type of MS. We also administered the Modified Fatigue Impact Scale (MFIS), ${ }^{26}$ the Pittsburg Sleep Quality Index (PSQI), and the Epworth Sleepiness Scale (ESS). The MFIS ${ }^{27}$ consists of twentyone items divided into three components: physical, cognitive, and psychosocial. Each item is scored from 0 (never) to 4 (almost always) for a score ranging from 0-84. A 
medRxiv preprint doi: https://doi.org/10.1101/2020.06.19.20136077; this version posted June 20, 2020. The copyright holder for this preprint (which was not certified by peer review) is the author/funder, who has granted medRxiv a license to display the preprint in perpetuity.

All rights reserved. No reuse allowed without permission.

higher score indicates a greater level of fatigue. The PSQI ${ }^{28}$ consists of 19 self-rated questions which form a global score ranging from of $0-21$ with a higher score indicating poorer sleep quality. The $\mathrm{ESS}^{29}$ consists of 8 different scenarios of daily activities, and participants rate how likely they would be to fall asleep during each activity with 0 (no chance of dozing) to 3 (high chance of dozing). The global score ranges from $0-24$ with a higher score indicates worse daytime sleepiness. Participants scoring 11 or higher on the ESS were considered having symptoms of daytime sleepiness.

\subsubsection{Driving simulation protocol:}

Daytime sleepiness was assessed using a house-modified virtual reality portable driving simulator (PDS) that was powered on STISIM Drive® (version 3, STI Inc, Hawthorne, CA) software (Figure 1). Images of the traffic scenario were projected on a single 22inch screen with 45 degrees field of view. Participants used a Logitech Steering wheel and pedals to navigate through the scenario. The vehicle engine sound and ambient traffic noise were heard through the simulator loudspeakers. All instructions were recorded in the software program and automatically played as participants progressed through the scenario. The scenario started with a warm-up section of about five minutes $(11,000 \mathrm{ft}$ or $3,353 \mathrm{~m})$ to gradually familiarize with the simulator software and hardware. In the familiarization, participants started on a two-lane road and were instructed to gradually increase their speed to 45 miles per hour. The two-lane road then transitioned into a four-lane road where participants were familiarized with highway driving by following a lead vehicle driving at a constant speed of 60 miles per hour. After the lead vehicle disappeared, the actual daytime sleepiness scenario started. This section took 
medRxiv preprint doi: https://doi.org/10.1101/2020.06.19.20136077; this version posted June 20, 2020. The copyright holder for this preprint (which was not certified by peer review) is the author/funder, who has granted medRxiv a license to display the preprint in perpetuity.

All rights reserved. No reuse allowed without permission.

about $20 \mathrm{~min}$ to complete and was $99,600 \mathrm{ft}(30,358 \mathrm{~m})$ long and consisted of rural interstate driving on straight roads with speed limits of 70 miles per hour with no to little ambient traffic. The driver's view was obstructed with dense fog that limited visibility beyond 1,000 ft (305 $\mathrm{m})$ ahead of the driver. The lack of cognitive stimulation by the driving simulation was purported to exacerbate daytime sleepiness.

Following driving simulator parameters were recorded at $60 \mathrm{~Hz}$ : (1) Time to completion (s), (2) distance over speed limit (\%), defined as the percentage of total distance drivers exceeded $70 \mathrm{mph}$; and (3) distance out of lane (\%), defined as the percentage of total distance drivers crossed the center line or the road edge.

Any symptoms of driving simulator sickness (i.e., simulator adaptation syndrome or SAS), were monitored for during the drive. The Simulator Sickness Questionnaire (SSQ) was administered after the drive to assess SAS. ${ }^{30}$ None of the drives were aborted due to severe SAS.

\subsubsection{Eye lid closure recording}

Eye lid closure was recorded while driving the simulator scenario using a remote eye tracker (FX3, SeeingMachines, Canberra, Australia) placed $11.4 \mathrm{~cm}$ in front of the screen with an upward angle of 12.8 degrees. Participants were seated $45 \mathrm{~cm}$ in front of the screen with their hands relaxed on the steering wheel.

The data extracted from the eye tracker and the driving simulator were synchronized using the Quad Server module of Eyeworks ${ }^{\circledR}$. Eyelids were tracked using the EyeWorks ${ }^{\circledR}$ Facekit Module that recorded eyelid closure on a continuous scale ranging from 0 (eyes fully closed) to 1 (eyes fully open). PERCLOS was defined in our study as the percentage of a time interval that the eyes were $80 \%$ to $100 \%$ closed (exclusive of 
blinks). ${ }^{31}$ The total time (i.e. number of frames) of the daytime sleepiness scenario was divided into 10 equal parts. PERCLOS was extracted for each time epoch, i.e., 0 - 10; $11-20 ; 21-30 ; 31-40,41-50,51-60,61-70,71-80,81-90$, and $91-100$ per cent of completion time.

\subsubsection{Data analysis}

Normality of variables was evaluated using visual inspection of histogram plots and Kolmogorov Smirnov tests. As can be expected due to relatively small sample size, assumptions of normality were violated in all continuous outcome measures, except for total scores on the MFIS. Consequently, non-parametric statistics were employed in all analyses. Group comparisons were evaluated using the Wilcoxon Rank Sum test for ordinal and ratio variables and the Fisher's Exact test for nominal variables. Generalized linear mixed models with random intercept was employed to evaluate the main effects of group and time, and the interaction effect of group by time, on PERCLOS. Results of demographic clinical variables were correlated with the overall change in PERCLOS (last epoch - first epoch) using Spearman $\rho$ correlations. All statistical analyses were conducted in SAS Enterprise Guide, version 8.2. P values $\leq 0.05$ were considered significant.

\section{Results}

3.1 Demographic and clinical variables 
We included 15 participants with MS and 15 controls matched for age, sex, education, and cognitive status (Table 1). All participants with MS had relapsing-remitting MS, except for one who was diagnosed with primary progressive MS. EDSS scores ranged from 1 to 6 , indicating very mild to moderately advanced disease stage. However, the majority $(75 \%)$ had mild to moderate symptoms of MS.

Participants with MS reported worse symptoms of fatigue than controls. The difference in total score on the MFIS $(p=0.003)$ was mainly driven by worse symptoms on the physical $(p=0.002)$ and cognitive subscales $(p=0.02)$ in iwMS. There were no group differences in the psychosocial subscale of the MFIS $(p=0.12)$.

Similarly, iwMS reported higher scores on the PSQI $(p=0.008)$, reflecting poorer sleep quality compared to healthy controls. By contrast, no differences were found in selfreported daytime sleepiness between the two groups $(p=0.45)$. Five $(33 \%)$ iwMS reported ESS scores of 11 or higher while three (20\%) in the control group reported scores higher than 11 (Fisher's Exact, $p=0.68$ ).

\begin{tabular}{|c|c|c|c|}
\hline Variable & $\mathrm{MS}(\mathrm{n}=15)$ & $\mathrm{HC}(\mathrm{n}=15)$ & $\begin{array}{l}P- \\
\text { value }\end{array}$ \\
\hline \multicolumn{4}{|l|}{ Demographic } \\
\hline Age, years & $55(50-59)$ & $48(46-53)$ & $0.09^{*}$ \\
\hline Sex, female (\%) & $12(80)$ & $11(73)$ & $0.31 \#$ \\
\hline
\end{tabular}




\begin{tabular}{|c|c|c|c|}
\hline Education, years & $14(12-16)$ & $16(15-18)$ & $0.10^{*}$ \\
\hline \multicolumn{4}{|l|}{ Clinical } \\
\hline MoCA, total & $25(23-27)$ & $27(24-28)$ & $0.13^{*}$ \\
\hline Disease duration, years & $8(4.5-15.5)$ & $\mathrm{N} / \mathrm{A}$ & \\
\hline EDSS, total & $2.5(2-3.25)$ & $\mathrm{N} / \mathrm{A}$ & \\
\hline MFIS, total & $40(27-54)$ & $15(11-29)$ & $0.003^{*}$ \\
\hline MFIS, physical & $15(11-25)$ & $5(1-13)$ & $0.002^{*}$ \\
\hline MFIS, cognitive & $16(12-31)$ & $13(7-14)$ & $0.02^{*}$ \\
\hline MFIS, psychosocial & $2(1-5)$ & $1(0-3)$ & $0.12^{*}$ \\
\hline PSQI, total & $10(6-13)$ & $4(3-8)$ & $0.008^{*}$ \\
\hline ESS, total & $8(5-13)$ & $8(4-10)$ & $0.45^{\star}$ \\
\hline \multicolumn{4}{|l|}{ Driving } \\
\hline Completion time, seconds & $1,153(1,147-1,172)$ & $\begin{array}{l}1,164(1,145- \\
1,196)\end{array}$ & $0.46^{*}$ \\
\hline Distance over speed limit, \% & $3.57(0.27-10.30)$ & $1.65(0-6.99)$ & $0.30^{*}$ \\
\hline Distance out of lane, \% & $0.10(0-0.29)$ & $0(0-0.30)$ & $0.78^{*}$ \\
\hline \multicolumn{4}{|c|}{$\begin{array}{l}\text { Abbreviations: ESS, Epworth Sleepiness Scale; MoCA, Montreal Cognitive } \\
\text { Assessment; MFIS, Modified Fatigue Impact Scale; PSQI, Pittsburgh Sleep Quality } \\
\text { Index }\end{array}$} \\
\hline \multicolumn{4}{|c|}{$\begin{array}{l}\text { *Wilcoxon Rank Sum test; \#Fisher's Exact test. Variables are expressed as median } \\
\text { (Q1 - Q3) or frequencies (\%). }\end{array}$} \\
\hline
\end{tabular}

3.2 Driving simulator variables 
medRxiv preprint doi: https://doi.org/10.1101/2020.06.19.20136077; this version posted June 20, 2020. The copyright holder for this preprint

(which was not certified by peer review) is the author/funder, who has granted medRxiv a license to display the preprint in perpetuity.

All rights reserved. No reuse allowed without permission.

None of the three driving simulator outcomes differentiated between the two groups (Table 1).

3.3 Percentage of eye closure over pupil

Figure 2 displays real-time daytime sleepiness, indexed by PERCLOS, in both groups as a function of percentage of completion time.

Generalized linear mixed modeling was employed to evaluate the effect of group, time, and the interaction effect of group by time on PERCLOS. Whereas group yielded no significant effect $(p=0.92)$, both groups showed more symptoms of daytime sleepiness as they progressed through the drive $(p<0.0001)$. The interaction effect of group by time demonstrated that participants with MS showed a different pattern of PERCLOS throughout the duration of the test compared to controls $(p=0.05)$. Comparing the PERCLOS of last with first epoch, individuals with MS exhibited greater increase in daytime sleepiness $(1.05 \%(0.40-2.14))$ compared to healthy controls $(0.31 \%(-0.40-$ 1.19); $p=0.04)$. IwMS closed their eyes an average $2.5 \%$ of the time in the last epoch of the drive, whereas healthy controls only dozed off $1.5 \%$ of the time in the last epoch.

Figure 2. Comparison of PERCLOS as a function of completion time between drivers with multiple sclerosis (MS) and healthy controls $(\mathrm{HC})$. 
medRxiv preprint doi: https://doi.org/10.1101/2020.06.19.20136077; this version posted June 20, 2020. The copyright holder for this preprint (which was not certified by peer review) is the author/funder, who has granted medRxiv a license to display the preprint in perpetuity.

3.4Correlations between demographic, clinical, driving simulator and change in PERCLOS.

Whereas none of the demographic, clinical, or driving simulator variables correlated significantly with change in PERCLOS (last epoch - first epoch) in the control group, disease duration $(\rho=0.63, p=0.04)$ and the percentage of distance out of lane $(\rho=$ $0.76, p=0.001)$ correlated strongly $(>0.50)$ with the change in PERCLOS in the MS group. No correlations were found between PERCLOS and any self-report daytime sleepiness, sleep quality, or fatigue scales.

Table 2. Spearman rho correlations between PERCLOS and demographic, clinical, and driving variables in the MS and control groups

\begin{tabular}{|l|l|l|l|l|}
\hline Variable & MS $(\mathrm{n}=15)$ & P-value & $\mathrm{HC}(\mathrm{n}=15)$ & P-value \\
\hline Demographic & & & & \\
\hline Age, years & 0.08 & 0.86 & -0.01 & 77 \\
\hline Sex, female (\%) & 0.14 & 0.61 & -0.12 & 0.65 \\
\hline Education, years & -0.40 & 0.16 & -0.07 & 0.82 \\
\hline Clinical & & & & \\
\hline MoCA, total & -0.10 & 0.72 & 0.26 & 0.35 \\
\hline Disease duration, years & 0.63 & 0.04 & $\mathrm{~N} / \mathrm{A}$ & $\mathrm{N} / \mathrm{A}$ \\
\hline EDSS, total & 0.35 & 0.20 & $\mathrm{~N} / \mathrm{A}$ & $\mathrm{N} / \mathrm{A}$ \\
\hline MFIS, total & -0.22 & 0.41 & 0.38 & 0.16 \\
\hline PSQl, total & 0.09 & 0.74 & -0.10 & 0.71 \\
\hline ESS, total & -0.21 & 0.44 & 0.006 & 0.98 \\
\hline
\end{tabular}




\begin{tabular}{|l|l|l|l|l|}
\hline Driving & & & & \\
\hline seconds & 0.30 & 0.27 & 0.04 & 0.88 \\
\hline $\begin{array}{l}\text { Distance over speed } \\
\text { limit, \% }\end{array}$ & -0.06 & 0.83 & 0.30 & 0.28 \\
\hline $\begin{array}{l}\text { Distance out of lane, \% } \\
\text { Abbreviations: ESS, Epworth Sleepiness Scale; MoCA, Montreal Cognitive }\end{array}$ \\
$\begin{array}{l}\text { Assessment; MFIS, Modified Fatigue Impact Scale; PSQI, Pittsburgh Sleep Quality } \\
\text { Index }\end{array}$ & 0.75 & 0.002 & 0.29 & 0.28 \\
\hline $\begin{array}{l}\text { *Wilcoxon Rank Sum test; \#Fisher's Exact test. Variables are expressed as median } \\
\text { (Q1 - Q3) or frequencies (\%). }\end{array}$ \\
\hline
\end{tabular}

\section{Discussion}

The aim of this study was to investigate the real-time effect of monotonous driving on daytime sleepiness in individuals with multiple sclerosis (iwMS). Our results showed that lack of cognitive stimulation from monotonous driving increased daytime sleepiness in both iwMS and controls. In addition, iwMS showed exacerbated symptoms of daytime sleepiness towards the end of the drive compared with controls. The lack of correlation between change in PERCLOS and ESS underscores the clinical importance of continuous, objective assessment in real-time during functional activities.

In a study by Neau et al., $32 \%$ of the iwMS had real-time assessed excessive daytime sleepiness, similar to the percentage (33\%) found in our study. ${ }^{32}$ Although slightly 
medRxiv preprint doi: https://doi.org/10.1101/2020.06.19.20136077; this version posted June 20, 2020. The copyright holder for this preprint (which was not certified by peer review) is the author/funder, who has granted medRxiv a license to display the preprint in perpetuity.

All rights reserved. No reuse allowed without permission.

higher, the prevalence of daytime sleepiness in iwMS did not differ statistically from that of control participants (20\%). One study found iwMS had higher daytime sleepiness using the Pupillographic Sleepiness Test (PST) and lower general wakefulness using the computerized Test of Attentional Performance (TAP) than controls compared to normative data. ${ }^{33}$ Interestingly, iwMS without select comorbidities, such as anemia, thyroid dysfunction, depressive symptoms or antidepressants, had significantly higher daytime sleepiness on the PST compared to controls but iwMS with select comorbidities did not. Both MS groups also showed lower general wakefulness compared to the control group. ${ }^{33}$

By contrast, our results support previous studies that found no differences in selfreported and real-time daytime sleepiness between iwMS and controls. Scores on other real-time daytime sleepiness assessments, such as the Multiple Sleep Latency Test (MSLT), did not demonstrate differences between iwMS with fatigue, iwMS without fatigue, and controls. ${ }^{34}$ Likewise, Taphoorn et al. reported no difference in the MSLT in a small sample of iwMS $(n=16)$ selected due to "prominent" fatigue and sleep disturbances compared to controls. ${ }^{35}$ Neau et al. did not demonstrate differences in MSLT between iwMS who reported fatigue with or without self-report excessive daytime sleepiness, but there was no control group to serve as a comparison. ${ }^{32}$ Another study found no significant difference in real-time daytime sleepiness using pupillography between iwMS and controls. ${ }^{36}$ Our study was the first to assess real-time daytime sleepiness in iwMS using a prolonged driving task which may be a more ecologically valid assessment of daytime sleepiness than lying down or sitting in a quiet, dark room. Support of this assertation is that both groups showed more symptoms of daytime 
medRxiv preprint doi: https://doi.org/10.1101/2020.06.19.20136077; this version posted June 20, 2020. The copyright holder for this preprint (which was not certified by peer review) is the author/funder, who has granted medRxiv a license to display the preprint in perpetuity.

All rights reserved. No reuse allowed without permission.

sleepiness as they progressed through the drive and iwMS exhibited a greater increase in daytime sleepiness despite the sample of iwMS and controls not reporting excessive daytime sleepiness (average ESS $<10$ for both groups).

No significant correlations were found between self-reported symptoms of fatigue, sleep quality, or daytime sleepiness and PERCLOS measures. This is perhaps not surprising as these are likely associated albeit different constructs. Paucke et al. reported a significant correlation between real-time daytime sleepiness (PST) and self-report sleep quality (PSQI) only for iwMS with select comorbidities but not in controls or iwMS without select comorbidities. ${ }^{33}$ Furthermore, while iwMS without select comorbidities exhibited higher real-time daytime sleepiness than controls, there was no significant correlation with fatigue (MFIS) or sleep quality (PSQI). Furthermore, Frauscher et al. reported no correlations between real-time daytime sleepiness (pupillography) and ESS or Stanford Sleepiness Scale in the general sample (iwMS and controls) or in the iwMS group. $^{36}$ In addition, Neau et al. reported MSLT was not correlated with ESS, ${ }^{32}$ and Kaynak et al. found no difference in ESS or MSLT between iwMS with and without fatigue, suggesting fatigue and daytime sleepiness may not be related. ${ }^{34}$ Furthermore, self-report measures can be influenced by social desirability, motives, memory, and depression whereas objective real-time assessments are likely less so. ${ }^{33}$

Whereas no significant? correlations between disease duration and self-reported daytime sleepiness were found in a previous study, ${ }^{37}$ our findings showed a significant correlation between disease duration and PERCLOS. Distance spent out of lane, an indicator of the ability to control the vehicle, has shown to correlate with daytime sleepiness in driving simulator studies. ${ }^{38}$ Both lateral vehicle control and daytime 
medRxiv preprint doi: https://doi.org/10.1101/2020.06.19.20136077; this version posted June 20, 2020. The copyright holder for this preprint (which was not certified by peer review) is the author/funder, who has granted medRxiv a license to display the preprint in perpetuity.

All rights reserved. No reuse allowed without permission.

sleepiness are important risk factors of MVC. Up to $15 \%$ of all MVC are related to sleepiness $^{39}$ and the risk of MVC when sleepy is between four and six times greater compared to driving while awake. ${ }^{40}$ Although the PERCLOS values remained low in both groups, the exacerbated symptoms of iwMS experienced at the end of the drive may increase the likelihood of MVC. This assumption should be tested in future studies.

The current study provides important knowledge on real-time daytime sleepiness in MS during functional activities. However, several limitations of the current study warrant caution in the interpretation of findings and generalization to the general population of drivers with MS. Our study sample was small and although we included participants with a wide range of disease severity, the majority had mild to moderate symptoms of MS. Likewise, only a minority of participants self-reported daytime sleepiness. Still, significant time and interaction effects were observed in PERCLOS in this group of participants with relatively preserved functions. We used a virtual reality driving simulator to mimic real-world driving. We cannot refute that driving behavior in the simulator may be different than driving in the real world. Although the scenario evoked daytime sleepiness, the drive was quite short (average of 25 minutes including warmup). Since our findings showed a difference in PERCLOS toward the end of the drive, future studies should include longer drives to assess the effect of prolonged driving on daytime sleepiness in MS.

In conclusion, we established the importance of evaluating daytime sleepiness using objective, real-time measures in a functionally relevant context. Although no differences were found between iwMS and controls on PERCLOS, iwMS exhibited exacerbated 
symptoms of daytime sleepiness towards the end of the drive. Future research should include longer assessment of daytime sleepiness during real-world driving.

Figure Legends:

Figure 1. Portable Driving Simulator with FX 3 Eye Tracker

1. Shell

2. Simulator screen

3. Steering wheel

4. Pedals

5. Simulator computer

6. Keyboard

7. FX3 eye tracker

Figure 2. Comparison of PERCLOS as a function of completion time between drivers with multiple sclerosis (MS) and healthy controls $(\mathrm{HC})$.

Funding:

This study was funded in part by a pilot research grant from the Department of Physical Therapy and Rehabilitation Science at The University of Kansas Medical Center. Dr. Devos and Dr. Akinwuntan co-invented the Portable Driving Simulator.

Acknowledgments: The authors thank Dr. Bunmi Morohunfola and Mr. Corey Gray for their assistance with data collection. 
medRxiv preprint doi: https://doi.org/10.1101/2020.06.19.20136077; this version posted June 20, 2020. The copyright holder for this preprint (which was not certified by peer review) is the author/funder, who has granted medRxiv a license to display the preprint in perpetuity.

\section{References}

1. Shen J, Barbera J, Shapiro CM. Distinguishing sleepiness and fatigue: focus on definition and measurement. Sleep Med Rev. 2006;10(1):63-76.

2. Hossain JL, Ahmad P, Reinish LW, Kayumov L, Hossain NK, Shapiro CM. Subjective fatigue and subjective sleepiness: two independent consequences of sleep disorders? J Sleep Res. 2005;14(3):245-253.

3. Popp RF, Fierlbeck AK, Knuttel H, et al. Daytime sleepiness versus fatigue in patients with multiple sclerosis: A systematic review on the Epworth sleepiness scale as an assessment tool. Sleep Med Rev. 2017;32:95-108.

4. Guidelines MSCfCP. Fatiuge and multiple sclerosis: evidence-based management strategies for fatigue in multiple sclerosis. Washington, DC: Paralyzed Veterans of America; 1998.

5. Braley TJ, Chervin RD. Fatigue in multiple sclerosis: mechanisms, evaluation, and treatment. Sleep. 2010;33(8):1061-1067.

6. Krupp LB, Alvarez LA, LaRocca NG, Scheinberg LC. Fatigue in multiple sclerosis. Archives of neurology. 1988;45(4):435-437.

7. American Academy of Sleep M. International classification of sleep disorders. 3rd ed. IL, USA: Darien; 2014.

8. Bonsignore MR, Marrone O, Fanfulla F. Sleep Apnea, Sleepiness, and Driving Risk. Sleep Med Clin. 2019;14(4):431-439.

9. Bioulac S, Micoulaud-Franchi JA, Arnaud M, et al. Risk of Motor Vehicle Accidents Related to Sleepiness at the Wheel: A Systematic Review and MetaAnalysis. Sleep. 2017;40(10).

10. Ryan KA, Rapport LJ, Telmet Harper K, et al. Fitness to drive in multiple sclerosis: awareness of deficit moderates risk. J Clin Exp Neuropsychol. 2009;31(1):126-139.

11. Schultheis MT, Weisser V, Manning K, Blasco A, Ang J. Driving behaviors among community-dwelling persons with multiple sclerosis. Arch Phys Med Rehabil. 2009;90(6):975-981.

12. Ranchet M, Akinwuntan AE, Tant M, Neal E, Devos H. Agreement Between Physician's Recommendation and Fitness-to-Drive Decision in Multiple Sclerosis. Archives of Physical Medicine and Rehabilitation. 2015;96(10):1840-1844.

13. Dehning M, Kim J, Nguyen CM, Shivapour E, Denburg NL. Neuropsychological performance, brain imaging, and driving violations in multiple sclerosis. Arch Phys Med Rehabil. 2014;95(10):1818-1823.

14. Schultheis MT, Garay E, Millis SR, Deluca J. Motor vehicle crashes and violations among drivers with multiple sclerosis. Arch Phys Med Rehabil. 2002;83(8):1175-1178.

15. Lings S. Driving accident frequency increased in patients with multiple sclerosis. Acta Neurol Scand. 2002;105(3):169-173. 
medRxiv preprint doi: https://doi.org/10.1101/2020.06.19.20136077; this version posted June 20, 2020. The copyright holder for this preprint (which was not certified by peer review) is the author/funder, who has granted medRxiv a license to display the preprint in perpetuity. All rights reserved. No reuse allowed without permission.

16. Krasniuk S, Classen S, Morrow SA, Tippett M, Knott M, Akinwuntan A. Clinical Determinants of Fitness to Drive in Persons With Multiple Sclerosis: Systematic Review. Arch Phys Med Rehabil. 2019;100(8):1534-1555.

17. Johns MW. A New Method for Measuring Daytime Sleepiness: The Epworth Sleepiness Scale. Sleep. 1991;14(6):540-545.

18. Johns MW, Chapman R, Crowley K, Tucker A. A new method for assessing the risks of drowsiness while driving. Somnologie. 2008;12:66-74.

19. Anderson C, Chang A-M, Sullivan JP, Ronda JM, Czeisler CA. Assessment of Drowsiness Based on Ocular Parameters Detected by Infrared Refl ectance Oculography. Journal of Clinical Sleep Medicine. 2013;13:907-920.

20. Lianga $\mathrm{Y}$, Horreya WJ, Howard ME, et al. Prediction of drowsiness events in night shift workers during morning driving. Accident Analysis \& Prevention. 2019;126:105-114.

21. Dinges DF, Grace RC. PERCLOS: A Valid Psychophysiological Measure of Alertness as Assessed by Psychomotor Vigilance. 1998.

22. Administration FH. PERCLOS: A valid psychophysiological measure of alertness assessed by psychomotor vigilance. In. Washington, DC: US Department of Transportation; 1998.

23. Thropp JE, Scallon JFV, Buza P. PERCLOS as an Indicator of Slow-Onset Hypoxia in Aviation. Aerospace Medicine and Human Performance. 2018;89(8):700-707.

24. Nasreddine ZS, Phillips NA, Bã@Dirian VR, et al. The Montreal Cognitive Assessment, MoCA: A Brief Screening Tool For Mild Cognitive Impairment. Journal of the American Geriatrics Society. 2005;53(4):695-699.

25. Kurtzke JF. Rating neurologic impairment in multiple sclerosis: an expanded disability status scale (EDSS). Neurology. 1983;33(11):1444-1452.

26. Flachenecker $\mathrm{P}$, Kumpfel $\mathrm{T}$, Kallmann B, et al. Fatigue in multiple sclerosis: a comparison of different rating scales and correlation to clinical parameters. Mult Scler. 2002;8(6):523-526.

27. Kos D, Nagels G, D'Hooghe MB, Duportail M, Kerckhofs E. A rapid screening tool for fatigue impact in multiple sclerosis. BMC Neurol. 2006;6:27.

28. Buysse DJ, Reynolds CF, 3rd, Monk TH, Berman SR, Kupfer DJ. The Pittsburgh Sleep Quality Index: a new instrument for psychiatric practice and research. Psychiatry Res. 1989;28(2):193-213.

29. Johns M. A new method for measuring daytime sleepiness: the Epworth sleepiness scale. Sleep. 1991;14(6):540-545.

30. Kennedy RS, Lane NE, Berbaum KS, Lilienthal MG. Simulator Sickness Questionnaire: An Enhanced Method for Quantifying Simulator Sickness. The International Journal of Aviation Psychology. 1993;3(3):203-220.

31. Li L, Xie M, Dong H. A method of driving fatigue detection based on eye location. Paper presented at: 2011 IEEE 3rd International Conference on Communication Software and Networks2011.

32. Neau J-P, Paquereau J, Auche V, et al. Sleep Disorders and Multiple Sclerosis: A Clinical and Polysomnography Study. European Neurology. 2012;68(1):8-15. 
medRxiv preprint doi: https://doi.org/10.1101/2020.06.19.20136077; this version posted June 20, 2020. The copyright holder for this preprint

(which was not certified by peer review) is the author/funder, who has granted medRxiv a license to display the preprint in perpetuity.

33. Paucke M, Kern S, Ziemssen T. Fatigue and Sleep in Multiple Sclerosis Patients: A Comparison of Self-Report and Performance-Based Measures. Frontiers in Neurology. 2018;8.

34. Kaynak H, Altintaş A, Kaynak D, et al. Fatigue and sleep disturbance in multiple sclerosis. European Journal of Neurology. 2006;13(12):1333-1339.

35. Taphoorn MJ, van Someren E, Snoek FJ, et al. Fatigue, sleep disturbances and circadian rhythm in multiple sclerosis. J Neurol. 1993;240(7):446-448.

36. Frauscher B, Egg R, Brandauer E, et al. Daytime sleepiness is not increased in mild to moderate multiple sclerosis: a pupillographic study. Sleep Medicine. 2005;6(6):543-547.

37. Pokryszko-Dragan A, Bilińska M, Gruszka E, Biel Ł, Kamińska K, Konieczna K. Sleep disturbances in patients with multiple sclerosis. 2013;34(8):1291-1296.

38. Soares S, Ferreira S, Couto A. Driving simulator experiments to study drowsiness: A systematic review. Traffic Injury Prevention. 2020;21(1):29-37.

39. Maycock G. Sleepiness and driving: the experience of UK car drivers. Journal of sleep research. 1996;5(4):229-231.

40. Klauer SG, Dingus TA, Neale VL, Sudweeks JD, Ramsey DJ. The impact of driver inattention on near-crash/crash risk: An analysis using the 100-car naturalistic driving study data. 2006. 


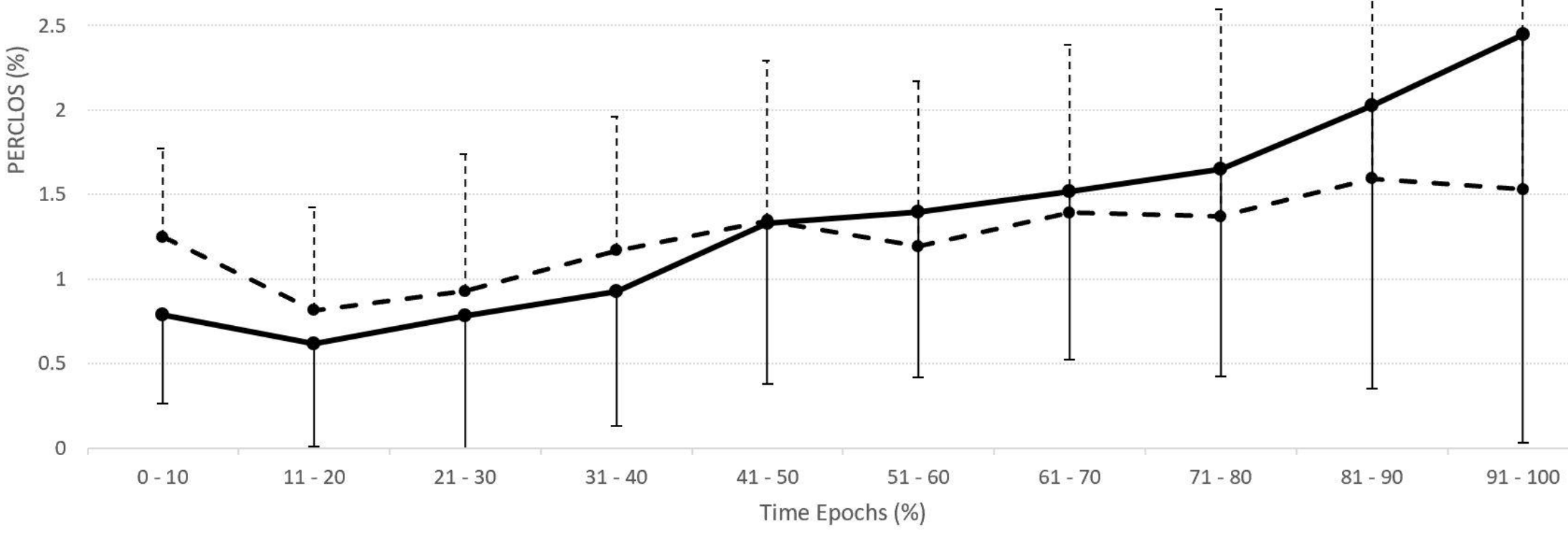

